\title{
Water and Air Relations in Propagation Substrates
}

\author{
Erin J. Yafuso and Paul R. Fisher \\ Environmental Horticulture Department, University of Florida, P.O. Box \\ 110670, Gainesville, FL 32611-0670
}

\author{
Ana C. Bohórquez \\ Research Service Centers, University of Florida, 1041 Center Drive, P.O. \\ Box 116621, Gainesville, FL 32611
}

\author{
James E. Altland \\ U.S. Department of Agriculture, Agriculture Research Service, Agricultural \\ Engineering Building, 1680 Madison Avenue, Wooster, OH 44691
}

Additional index words. CT, moisture retention, peat, phenolic foam, rockwool, tomography

\begin{abstract}
Greenhouse propagation of unrooted plant cuttings is characterized by short container cell height and high irrigation frequency. These conditions can result in high moisture level and low air content in soilless container substrates ("substrates"), causing delayed growth of adventitious roots and favoring root disease. The objective of this study was to quantify and compare substrate water and air relations for three propagation substrates (peat, rockwool, and phenolic foam) that varied widely in physical characteristics using four methods: 1) evaporation method with a tensiometer, 2) frozen column method, 3) gravimetric analysis, and 4) X-ray computed tomography (CT) analysis. Moisture retention curves based on evaporation (1) and the frozen column (2) resulted in differences for peat, but similar curves for rockwool and foam. The frozen column method was simple and low cost, but was constrained by column height for peat, which had a higher water potential compared with the other two substrates. Substrate porosity analysis at container capacity by gravimetric or CT methods were similar for volumetric water and air content (VWC and VAC) in rockwool and foam, but differed for peat for VWC and VAC. Gravimetric analysis was simple, rapid, and low cost for whole-cell analysis, but CT further quantified spatial water and air relations within the cell and allowed visualization of complex water and air relations in an image. All substrates had high water content at container capacity ranging from $67 \%$ to $91 \%$ VWC with $5 \%$ to $11 \%$ VAC in the short propagation cells, emphasizing the need for careful irrigation management.
\end{abstract}

During propagation of plant cuttings, high humidity and frequent mist irrigation are provided to hydrate unrooted cuttings, encourage callus development, and stimulate adventitious root formation (Santos et al., 2011); however, overwatering can potentially delay rooting and increase disease risk (Chérif et al., 1997; Heiskanen, 1995; Leakey, 2004). An appropriate combination of substrate selection and irrigation practices is therefore needed to balance adequate supply of water for propa-

Received for publication 19 Apr. 2019. Accepted for publication 29 July 2019 .

This research is supported by the National Institute of Food and Agriculture, U.S. Department of Agriculture, "Clean WateR ${ }^{3}$ - Reduce, Remediate, Recycle," \#2014-51181-22372. We thank our industry partners in the Floriculture Research Alliance (FloricultureAlliance.org) for their financial support and supply of materials. We thank James C. Colee from University of Florida Agriculture Statistics for providing the statistical models and analytical methods to compare nonlinear curves. P.R.F. is the corresponding author. E-mail: pfisher@ufl.edu.

This is an open access article distributed under the CC BY-NC-ND license (https://creativecommons.org/ licenses/by-nc-nd/4.0/). gule hydration and oxygen supply for root respiration, both of which are requirements for rapid root growth, development, and subsequent plant health (Bilderback and Lorscheider, 1995; Reisch, 1967).

The combination of short container height and fine substrate particles in propagation increases risk of inadequate gas exchange in the substrate. A wide range of substrates and amendments is used during young plant production, including peat (sphagnum), bark, coir, wood fiber, vermiculite, perlite, phenolic foam, and rockwool (Fonteno and Nelson, 1990; Handreck and Black, 2002; Milks et al., 1989a). Fine particle sizes of these components are often required to evenly fill small container cells, resulting in decreased pore size and higher water retention (da Silva et al., 1993). Container size modifies the ratio of water and air within the substrate, because as column height decreases, there is an increased proportion of water and corresponding reduction in air (Argo et al., 1996; Handreck and Black, 2002; Milks et al., 1989b, 1989c; Rivière and Caron, 2001). Physical properties of propagation substrates are further modified by the use of "stabilized" substrates, which include phenolic foam, peat-polymer blends, fabric-wrapped cells, and other materials that hold the substrate together negating the need for a complete root ball and allowing for a shorter crop cycle and a reduction in transplanting stress (Huang and Fisher, 2014).

For gravimetric analysis of physical properties, substrates at a standardized volume and level of compaction are weighed at full saturation, after drainage, and after drying to quantify $\mathrm{VWC}, \mathrm{VAC}$, volumetric solid content (VSC), and dry bulk density (Fonteno, 1993). The porometer method (Fonteno, 1993) uses a $348 \mathrm{~cm}^{3}$ standard volume that can be modified for propagation plug cells with a shorter column height (Milks et al., 1989c). The maximum and minimum ratio of water to air at container capacity (which is the field capacity within a particular container type) describes the substrate water-air relations, with typical levels of $45 \%$ to $65 \%$ water and $10 \%$ to $30 \%$ air space with a variety of substrates (Bilderback et al., 2005) using the volume pressure plate extractor (Milks et al., 1989a) in $348-\mathrm{cm}^{2}$ containers $(7.3-\mathrm{cm}$ diameter $\times 7.6$ $\mathrm{cm}$ height). However, water and air balance is highly dependent on container size and shape, with air-filled porosity decreasing from $19 \%$ to less than $1 \%$ as substrate height decreased from a $15-\mathrm{cm}$-tall pot to a $1.3-\mathrm{cm}$-tall seedling plug tray based on a modeled peat-vermiculite substrate (Caron and Nkongolo, 1999). Gravimetric measurements also can be made directly in propagation trays, or with individual stabilized cells that do not easily conform to a standard porometer shape and volume (Huang and Fisher, 2014). A survey of commercial propagation substrates found widely differing physical properties, with loose-filled products having VWC from $57 \%$ to $86 \%$ and VAC ranging from $4.8 \%$ to $9.7 \%$ in $25 \mathrm{~cm}^{3}$ cells. In contrast, stabilized substrates had a VWC from $37 \%$ to $91 \%$ and VAC between $1.9 \%$ and $5.9 \%$ in 10 - to $28-\mathrm{cm}^{3}$ cells (Huang and Fisher, 2014). A limitation of gravimetric analysis at one moisture level is that it ignores the dynamic change in air and water as moisture level changes during crop production (Caron and Nkongolo, 1999).

Water potential of a substrate, and the relationship between VWC and plant available water, are usually measured as a substrate dries from saturation over time by measuring the tension of water using a ceramic-tip tensiometer (Wallach, 2008). Moisture retention curves (MRCs) describe water availability for uptake by plant roots. Water held in substrate below $50 \mathrm{~cm}$ of tension has been defined as easily plant available water, 50 to $100 \mathrm{~cm}$ describes water-buffering capacity that is available to plants during periods of rapid transpiration, whereas tension above $100 \mathrm{~cm}$ may not be available for plant root uptake (DeBoodt and Verdonck, 1972; Naasz et al., 2005). In horticultural production in containers, the tension at which wilting occurs depends on the plant species and growing conditions (DeBoodt and Verdonck, 1972). For example, Kiehl et al. (1992) found that potted chrysanthemum grown under moist conditions wilted above $10 \mathrm{kPa}(102 \mathrm{~cm})$, and 
recommended automatic irrigation triggered at a tension of $5 \mathrm{kPa}(51 \mathrm{~cm})$. Because plant cuttings initially have limited or no roots, the moisture level is typically maintained close to container capacity during callus formation (Gislerød, 1983; Healy, 2008), and gradually changes to wet-dry cycles following the emergence of adventitious roots to provide aeration (Loach, 1988). In propagation, many cells are also shorter than $5 \mathrm{~cm}$ (Huang and Fisher, 2014; Milks et al., 1989c), and differences in moisture and air level at low tensions are therefore of great importance.

An alternative method to generate an MRC is the use of the frozen column method, whereby the substrate is brought to field capacity, frozen, and then sectioned to quantify VWC and VAC within each vertical section (Altland et al., 2010; Dane and Hopmans, 2002; Owen and Altland, 2008). The VWC using the frozen column method allows a comparison between the water potential from the column height to the water potential measured using a tensiometer. In this study, Altland et al. (2010) found similar, but statistically different, MRCs for bark-based substrates tested with either the pressure plate or frozen column (core) methods, with the pressure plate method estimating a higher water content at saturation, slightly lower moisture levels at tensions below $10 \mathrm{~cm}$, and similar moisture levels at higher tensions compared with the frozen column method.

Through a more recently developed method, X-ray CT, the root zone microenvironment of water and air relations can be quantified and visualized (Daly et al., 2015; Nimmo, 2004) in addition to root morphology (Tracy et al., 2013, 2015a, 2015b). Daly et al. (2015) CT-scanned clay and sand substrates at different moisture levels and found that estimating or modeling VWC and VAC and other physical properties by $\mathrm{CT}$ provided a complementary method to using a ceramic plate or gravimetric measurement.

Because of the small container size, specialized materials, and the high moisture conditions in propagation, standard testing protocols need to be modified for quality control testing in propagation substrates (Huang and Fisher, 2014). The objective of this study was to quantify and compare substrate water and air relations of three propagation substrates (peat, rockwool, and phenolic foam) that varied widely in physical characteristics by using four methods: 1) MRCs by evaporation, 2) frozen column, 3) gravimetric analysis, and 4) CT analysis. The goal was to identify strengths and weaknesses of each method for quality control testing for propagation substrates and to inform substrate selection and irrigation management for plant propagation.

\section{Materials and Methods}

Experiments were conducted in laboratories at the University of Florida (UF) in Gainesville, FL. Substrates consisted of peat, rockwool, and phenol-formaldehyde foam. The sphagnum peatmoss ("peat") was a
$100 \%$ sod peat sourced from Lithuania (Von Post scale 2-3; Puustjarvi and Robertson, 1975) with a $\mathrm{pH}$ of 5.7 and an electric conductivity of $1.6 \mathrm{mS} \cdot \mathrm{cm}^{-1}$. The particle size distribution of the peat was tested with three 1-L replicates, resulting in (by volume) $27.6 \%$ coarse $(>2.0 \mathrm{~mm}), 69.1 \%$ medium $(0.5$ to $2.0 \mathrm{~mm}), 2.6 \%$ fine $(150 \mu \mathrm{m}$ to $0.5 \mathrm{~mm})$, and $0.9 \%$ dust $(<150 \mu \mathrm{m})$ based on the methodology and description of particle size categories from Huang et al. (2012a) and Huang and Fisher (2014). Peat had a dry bulk density of $87.5 \mathrm{~g} \cdot \mathrm{L}^{-1}$, and organic matter was $90.8 \%$, with $52.7 \%$ carbon and $1.1 \%$ nitrogen, and a $\mathrm{C} / \mathrm{N}$ ratio of $46.6(\mathrm{QAL}$, Panama City, FL). Rockwool plugs (Grodan, Roermond, the Netherlands) were composed of basalt and limestone heated to $1600{ }^{\circ} \mathrm{C}$, forming threads of $5 \mu \mathrm{m}$, and the average pore size was 4.5 to $5.0 \mu \mathrm{m}$ (da Silva et al.,1995), with a dry bulk density of 78.9 $\mathrm{g} \cdot \mathrm{L}^{-1}$. Phenol-formaldehyde foam [Oasis, Kent, OH ("foam")] root cubes with a dry bulk density of $20.3 \mathrm{~g} \cdot \mathrm{L}^{-1}$ were composed of a foam matrix with monodispersed pore distribution (Milks et al., 1989b).

Method 1. MRCs using evaporation. The evaporation method (Hyprop; UMS, Munich, Germany) was used for each substrate described by Fields et al. (2016) to plot MRCs. Samples were subirrigated to saturation for $24 \mathrm{~h}$ in a basin. Cores of $250-\mathrm{mL}$ volume (8$\mathrm{cm}$ diameter and 5-cm height) were drained for $15 \mathrm{~min}$, and weighed to determine the initial water-holding capacity. With rockwool samples, two holes were bored at two depths $(3.8 \mathrm{~cm}$ and $1.3 \mathrm{~cm}$ from the base) using an auger positioning tool. The tensiometer base, equipped with two tensiometers $(1.3-\mathrm{cm}$ and $3.8-\mathrm{cm}$ tall), was fixed to each beveled core with substrate, fitting tensiometers precisely into the bored holes. For peat and foam samples, the tensiometers were pushed through to create their own holes. Water potential from the two tensiometers and weight of the assembly were recorded every $10 \mathrm{~min}$ (Tensioview software, Munich, Germany). Measurements continued until water in the upper tensiometer cavitated after $\approx 10 \mathrm{~d}$ (ranging between experimental runs between 295.8 and $440.6 \mathrm{~cm}$ for peat, 39.5 and $45.2 \mathrm{~cm}$ for rockwool, and 25.0 and 27.2 $\mathrm{cm}$ for foam). Substrates were removed from the core, dried in a forced-air oven at $105^{\circ} \mathrm{C}$ for $48 \mathrm{~h}$, and weighed. Data were analyzed using a modified van Genuchten (1980) fourparameter log-logistic model (Eq. [1]) where VWC $(\theta)$ is a function of pressure $(h$, in $\mathrm{cm})$.

Parameters were fitted with nonlinear regression (PROC NLIN in SAS Version 9.4, SAS Institute, Cary, NC).

$$
\theta=\theta \mathrm{r}+(\theta \mathrm{s}-\theta \mathrm{r}) /\left[\left(1+\left(\mathrm{h} / \mathrm{X}_{0}\right)^{\mathrm{n}}\right]\right.
$$

The parameter $\theta_{s}$ represented the VWC at saturation (zero tension), $\theta_{r}$ was the residual VWC (lower asymptote), $h$ was the column height (relative to the bottom), $X_{0}$ was the inflection point in the sigmoid curve, and $n$ was a rate parameter (Altland et al., 2010). The MRCs generated using the evaporation method were compared between substrates using a paired-sample $t$ test of the nonlinear fitted Eq. [1], with a separate $t$ test for each possible paired comparison of substrates. In addition, the estimates and $95 \%$ confidence intervals for the four parameters from nonlinear regression were tabulated and compared between substrates.

Method 2. Moisture retention curve by frozen column method. The frozen column method was used to generate MRCs of the three substrates (peat, rockwool, and foam) at container capacity, with four replicates per substrate (Altland et al., 2010; Owen and Altland, 2008). Peat was filled into $3.8-\mathrm{cm}$ diameter clear plastic tubes of $30.5-\mathrm{cm}$ length and dropped at a height of $6 \mathrm{~cm}$ three times to provide consistent compaction. Rockwool and foam plugs were $3.4-\mathrm{cm}$ diameter and $34 \mathrm{~cm}$ in height. The substrates were subirrigated to a water level of $25 \mathrm{~cm}$ to provide complete saturation for $4 \mathrm{~h}$, followed by drainage for $30 \mathrm{~min}$. Substrate samples were stored at $-6.6{ }^{\circ} \mathrm{C}$ for 2 days, and the frozen substrate was then sectioned at $1-\mathrm{cm}$ heights using a horizontal band saw. For each section, the width and height were measured with a digital caliper. Gravimetric measurements were recorded when sectioned samples defrosted and dried. VWC and VAC were calculated for each 1-cm section. VWC as a function of column height data were fitted to the nonlinear model Eq. [1], and obtained the fit parameters $\theta_{\mathrm{s}}, \theta_{\mathrm{r}}, \mathrm{n}$, and $\mathrm{X}_{0}$. Differences between substrates for the frozen column method were compared using the same analytical approaches described for evaporation ( $t$ test and comparing parameter estimates). In addition, within each substrate there was a comparison between evaporations and the frozen column methods using these statistical approaches.

Method 3. Gravimetric whole-cell analysis. Porosity was measured for the original container dimensions and shape of the propagation cells. Substrates were saturated by adding water to a basin with propagation substrate up to $1 \mathrm{~cm}$ to the top overnight followed by draining for $30 \mathrm{~min}$ to achieve container capacity. Gravimetric measurements were recorded at saturation, container capacity, and after drying to calculate VWC, VAC, and VSC, using the methods described by Huang et al. (2012b) and Huang and Fisher (2014), with direct measurements of porosity within propagation trays. There were three replicate cells for each substrate at container capacity. The $55-\mathrm{mL}$ cells were filled with peat, whereas rockwool plugs were $40.5 \mathrm{~mL}$, and the foam root cubes were $30.5 \mathrm{~mL}$

Method 4. X-ray tomography (CT) wholecell analysis. Each substrate was brought to container capacity, as described for the gravimetric whole-cell analysis (method 3 ), and were scanned using CT with a $240-\mathrm{kV}$ Xray tube with a tungsten target $(\mathrm{v} \mid$ tome $\mid \mathrm{x} M$ 240; GE, Boston, MA) at UF, Research Service Centers (1041 Center Drive, P.O. Box 116621, Gainesville, FL 32611). An additional three replicate cells of peat were on 
capillary mats and equilibrated to $51 \%$ VWC and were also scanned. The scanned settings were a voltage of $80 \mathrm{kV}$, current of $175 \mu \mathrm{A}$, and 200-ms detector time, averaging three images with a skip of one image per rotation with total of 1000 images, and a voxel resolution of $59.5 \mu \mathrm{m}$. Raw two-dimensional projections were processed (datos|x software v. 2.3; GE Sensing \& Inspection Technologies $\mathrm{GmbH}$, Wunstorf, Germany) before importing into VG StudioMax 3.0 (Volume Graphics, Heidelberg, Germany) to perform segmentation and three-dimensional (3D) visualization.

A combination of image segmentation from CT and results from gravimetric analy- sis of the solid component was used to quantify VWC and VAC for substrates in propagation cells. First, volume of the 3D representation of a cell was defined by removing border sections that included edge areas outside the solid propagation cell, and was then segmented by creating regions of interest by intensity (density) threshold or using the region-growing tool within $\mathrm{VG}$ StudioMax 3.0. This allowed the volume to be differentiated into two densities: 1) the air volume and 2) the volume of the combined matrix of water plus solid substrate. Second, gravimetric analysis of VSC from gravimetric whole-cell analysis was used as a constant
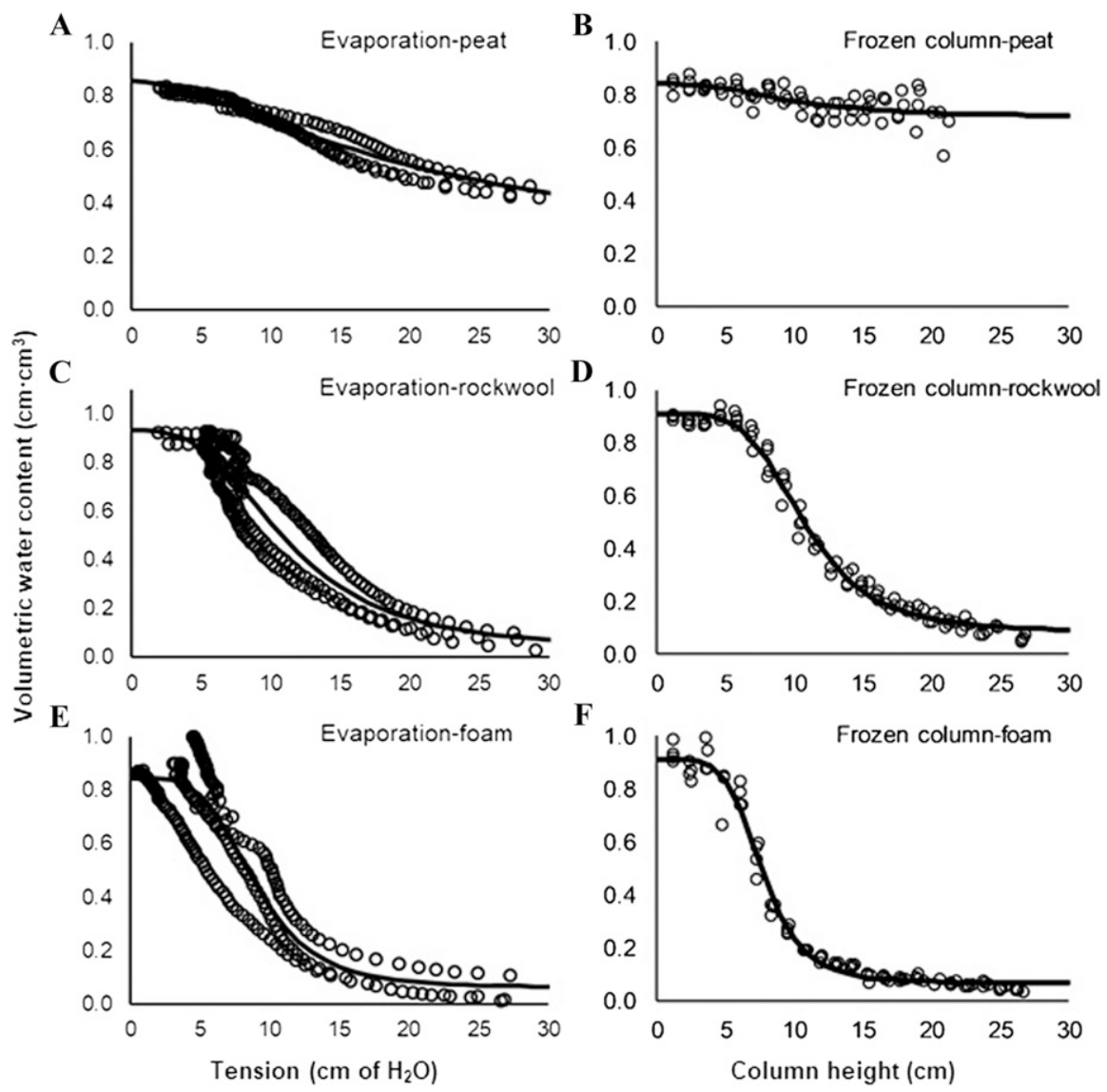

Fig. 1. Moisture retention curves by evaporation or frozen column methods for peat $(\mathbf{A}, \mathbf{B})$, rockwool $(\mathbf{C}$, D), and foam $(\mathbf{E}, \mathbf{F})$. Evaporation analysis was the result of $\mathrm{n}=3$ runs per substrate. Frozen column analysis was the result of $n=4$ per substrate. to subtract the solid portion from (2) water. This approach was necessary because image segmentation of water was not possible in peat because water enters internal pores of peat resulting in a similar density between water and the combined water/peat matrix. Percent VAC was calculated by dividing the segmented volume of air by the segmented total volume. Percent VWC was calculated by subtracting VAC and VSC from 1 .

Data for VWC and VAC from the gravimetric and CT whole-cell analysis were compared using a two-way analysis of variance (ANOVA) by PROC GLIMMIX with fixed effects of the three substrates and two methods (gravimetric or CT) at $\alpha=0.05$ in SAS. Spatial distribution of water and air content within each cell was quantified by sectioning the vertical profile by $0.5-\mathrm{cm}$ increments using the 3D-polyline tool in parallel view (VG Studio Max 3.0). There were three replicates per substrate at container capacity, plus peat at $51 \%$ VWC. Data for the three substrates at container capacity were analyzed statistically by a two-way ANOVA, with fixed effects of substrate and cell depth and their interaction.

\section{Results and Discussion}

Method 1. MRCs by evaporation method. At no tension (saturation), peat held a similar amount of water to the other two substrates (as shown by comparisons of Fig. 1A, C, and $\mathrm{E}$, and estimates of $\theta_{s}$ in Table 1). However, peat had a much higher water potential, meaning more water was retained as moisture tension increased (represented by the rate parameter $n$ and residual VWC parameter $\theta_{r}$ in Table 1). The MRC resulted in acceptable $R^{2}$ values ranging from 0.44 to 0.99 to the model fit for all substrates (Table 1). Peat at saturation was estimated at $86 \% \operatorname{VWC}\left(\theta_{s}\right.$ in Table 1). As substrate dried, the inflection point was near $58 \%$ VWC or tension of $19 \mathrm{~cm}$ and decreased to residual VWC at $23 \%\left(\theta_{r}\right.$ in Table 1). At tensions above $200 \mathrm{~cm}$ (beyond the data displayed in Fig. 1A), measured VWC in peat was within $5 \%$ of the estimated $\theta_{r}$. As substrate dried, plant easily available water (below $50 \mathrm{~cm}$ ) for peat ranged from $86 \%$ to $34 \%$ VWC, and plant available water $(50$ to $100 \mathrm{~cm}$ ) ranged from $34 \%$ to $27 \%$ VWC. Water below $27 \%$ VWC was beyond

Table 1. Model estimates using a four-parameter log-logistic model for moisture retention curves of three substrates and two methods of evaporation or frozen column substrate. Evaporation analysis was the result of $n=3$ runs per substrate. Frozen column analysis was the result of $n=4$ per substrate. Confidence intervals $( \pm)$ were set at 0.05 . The parameters for the log-logistic model were $\theta_{\mathrm{s}}=$ water content at saturation, $\theta_{\mathrm{r}}=$ residual water content, $\mathrm{n}=$ is a rate parameter, and $\mathrm{X}_{0}=$ tension due to curve change from convex to concave or inflection point.

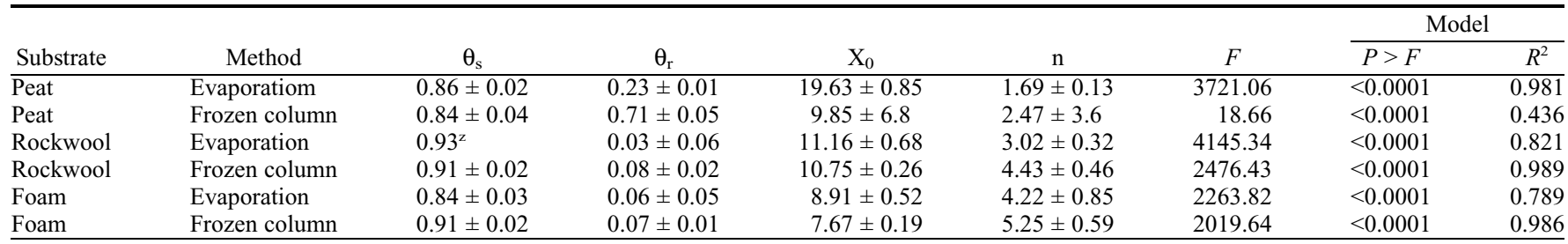

${ }^{\mathrm{z}}$ The parameter $\theta_{s}$ was set as a constant of 0.93 for rockwool for the evaporation curves based on the measured total porosity in the Hyprop system, because otherwise the nonlinear regression estimates were not close to the observed porosity for this substrates. 
$100 \mathrm{~cm}$ of tension and unavailable to plants, based on the model. Within peat substrates, water at high tension is largely bound within internal pores in peat fibers or granules, whereas freely available water is in larger pores between peat particles (Rivière and Caron, 2001). Peat is a widely used component in container propagation substrates in the United States, and although high waterbuffering capacity reduces risk of dehydration of cuttings, a peat-based substrate can easily become waterlogged unless mist irrigation is carefully controlled.

Rockwool and foam held water at low tensions (i.e., had low water-buffering capacity as residual water content was less than 50 $\mathrm{cm}$ ) and essentially all water was available for plant uptake. Model fit for MRCs resulted in a high correlation $\left(R^{2}=0.82\right.$ and 0.79 for rockwool and foam, respectively). Based on the measured data from the evaporative method, the saturated parameter for rockwool in Eq. [1] was set as a parameter constant value of $93 \%$ during model fitting because the predicted parameter $\theta_{s}$ exceeded $100 \%$. The VWC declined to near the estimated $\theta_{r}$ of $3 \%$ at low tension of $30 \mathrm{~cm}$ (Fig. 1B; Table 1). Similar studies by da Silva et al. (1995) with rockwool resulted in saturation at $95 \% \mathrm{VWC}$, but rapidly decreased to nearly zero water content at a tension of $51 \mathrm{~cm}(5 \mathrm{kPa})$. Foam at saturation was estimated to have $84 \%$ VWC; however, there was high variability in the data at low tensions (Fig. 1E). Similar to rockwool at $30 \mathrm{~cm}$ of tension, the VWC of foam was close to $\theta_{r}$ of $6 \%$. In comparison, the MRC for foam by Milks et al. (1989a) also declined to nearly $3 \% \mathrm{VWC}$ at $\approx 50 \mathrm{~cm}$ of tension. Low water-buffering capacity of rockwool and foam may require more frequent irrigation under high evapotranspiration conditions (da Silva et al., 1995; Fonteno and Nelson, 1990).

Method 2. Moisture retention curve by frozen column method. The estimated MRCs from the frozen column method for peat (Table 1 ) had a lower $R^{2}$ value (0.44) compared with other substrates and methods because 1) the column height was only $21 \mathrm{~cm}$, whereas the evaporation data indicated $\theta_{r}$ was approached at much higher tensions, and 2) some variability in data points in the 0 - to $30-\mathrm{cm}$ range (Fig. 1B) occurred due to column diameter (frozen column diameter was $3.8 \mathrm{~cm}$ compared with $8 \mathrm{~cm}$ core diameter for tensiometer). This uncertainty also was reflected in the broader confidence intervals for peat with the frozen column method than the evaporation method (Table 1). Peat averaged $82 \%$ VWC in the lower $10 \mathrm{~cm}$ of the column, similar to the $\theta_{s}$ estimate of $84 \% \pm 4 \%$ by evaporation, and only decreased slightly to $75 \%$ in the upper half of the column (10 to $21 \mathrm{~cm}$ ) (Fig. 1B).

The frozen column method for rockwool and foam resulted in higher $R^{2}$ values $(0.99)$ because the entire function describing the MRC fell within the range of measured column heights (Table 1). Rockwool held 91\% VWC at saturation, then decreased to $76 \%$ at the inflection point $(10.8 \mathrm{~cm})$, further decreasing to $8 \%$ at $27-\mathrm{cm}$ tension (Fig. 1D). Similarly, foam held $91 \%$ VWC at saturation, which decreased
Table 2. Summary of the information provided, the cost for laboratory equipment, and the necessary level of technical operator skill for the four different substrate analysis methods evaluated in this article, along with published research.

\begin{tabular}{llcc}
\hline Method & \multicolumn{1}{c}{ Information provided } & Equipment cost (\$) & Operator skill level \\
\hline Evaporation & Dynamic and static characteristics & Moderate & High \\
& Moisture retention curve & & \\
& Hydraulic conductivity & & \\
& Water-holding capacity & & Moderate \\
& Air-filled porosity & & \\
Frozen column & Bulk density & Low & \\
& Dynamic and static characteristics & & \\
& Moisture retention curve & & \\
& Water-holding capacity & & \\
& Air-filled porosity & Low & \\
Gravimetric & Bulk density & & \\
& Static characteristics & & Very high \\
& Water-holding capacity & High \\
Air-filled porosity & & \\
Bomputed & Bulk density & & \\
& Static characteristics & & \\
& Visualization of water and air & & \\
& Spatial distribution of water and air & & \\
& Water-holding capacity & & \\
\hline
\end{tabular}

Table 3. Summary of whole-cell analysis by gravimetric or computed tomography (CT) for volumetric water content (VWC) and volumetric air content (VAC) for the three propagation substrates at container capacity. Substrate solid, content was estimated by gravimetric analysis and solid values ( $22 \%$ for peat, $8 \%$ for rockwool, and $2 \%$ for foam) were treated as a constant for each substrate. Leastsquare means for gravimetric and CT analysis were the result of $n=3$ cells for each treatment combination, and letters after VWC and VAC represent mean separation using Tukey's honestly significant difference at $\alpha=0.05$

\begin{tabular}{llcr}
\hline Substrate & Methods & VWC, \% & VAC, \% \\
\hline Peat & Gravimetric & $65 \mathrm{~b}$ & $11 \mathrm{a}$ \\
& CT & $70 \mathrm{a}$ & $6 \mathrm{~b}$ \\
Rockwool & Gravimetric & $87 \mathrm{a}$ & $5 \mathrm{a}$ \\
& CT & $87 \mathrm{a}$ & $5 \mathrm{a}$ \\
\multirow{2}{*}{ Foam } & Gravimetric & $91 \mathrm{a}$ & $7 \mathrm{a}$ \\
& CT & $93 \mathrm{a}$ & $5 \mathrm{a}$ \\
\hline
\end{tabular}

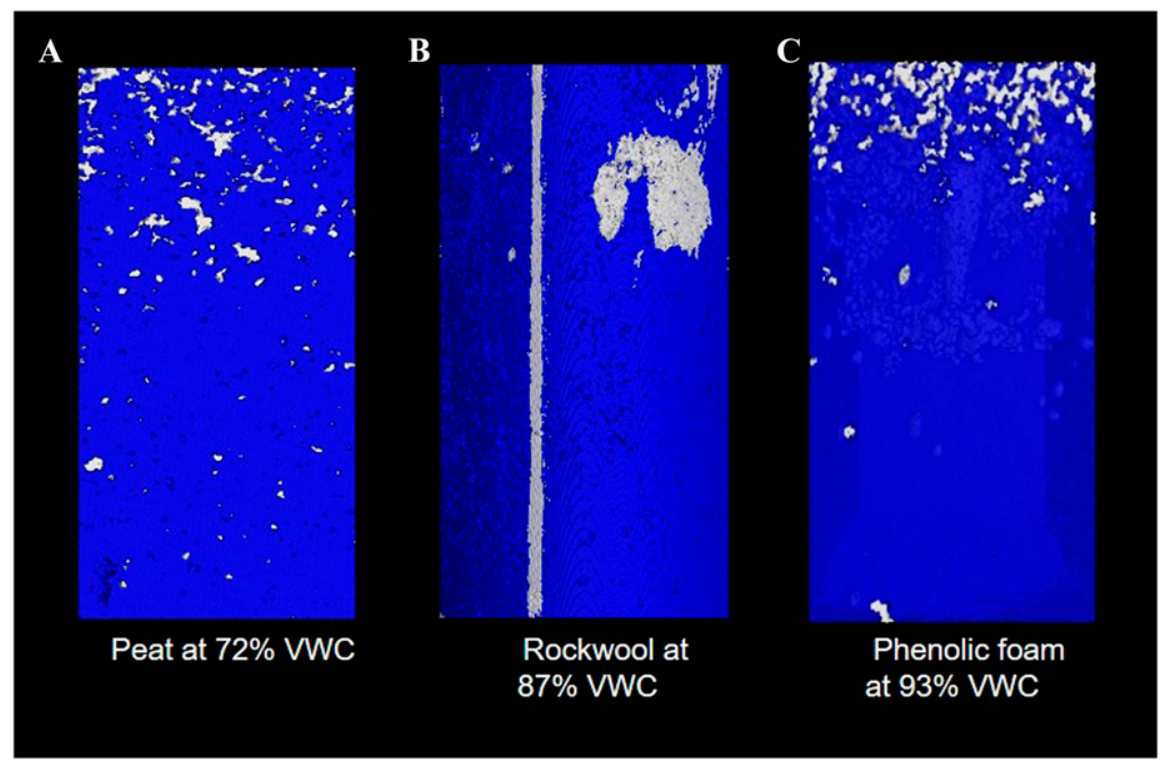

Fig. 2. Images of computed tomography-scanned substrate showing the water and air distribution in substrates at container capacity in propagation-sized cells. Images show one example scan per substrate (A-C). Container capacity was achieved by overnight subirrigation of substrates, followed by draining for $30 \mathrm{~min}$. Substrate with dark gray color represents segmented water-solid matrix in peat or water in rockwool and foam, and white to light gray represents segmented air. Images are not to scale; actual volume of peat was $55 \mathrm{~mL}$, rockwool was $40.5 \mathrm{~mL}$, and foam was $30.5 \mathrm{~mL}$. 
to $58 \%$ at the inflection point $(7.7 \mathrm{~cm})$, and further decreased to $7 \%$ at $27-\mathrm{cm}$ tension (Fig. 1f). In both substrates, the frozen column method clearly demonstrated low water potential, with VWC less than $10 \%$ at the top of the column (less than $30 \mathrm{~cm}$ in height). In a short propagation cell, this may not lead to high stratification of moisture, but this low water potential would have a large impact on vertical water and air distribution in taller containers.

The two methods for MRCs resulted in significant differences for peat $(P<0.001)$ but not for rockwool and foam based on the pairedsample $t$ test. In peat, confidence intervals for the curve parameters $\theta_{r}, X_{0}$, and $n$ did not overlap between methods (Table 1). Experimentally for the frozen column method, using a column height of $100 \mathrm{~cm}$, use of a piezometer, and possibly additional time for soaking the substrate beyond $4 \mathrm{~h}$ would improve the resolution of the MRC for peat and better describe plant available water. In rockwool, confidence intervals for curve parameters overlapped between methods with the exception of the rate parameter $(n)$, although as noted previously, the $\theta_{s}$ parameter was set as a constant when fitting Eq. [1] for the evaporation data (Table 1). In foam, although curve-fitting parameters of $\theta_{s}$ and $X_{0}$ did not overlap, the $t$ test comparison did not show significant differences between methods. Comparison of MRCs by paired $t$ test within a method (evaporation or frozen column) for all possible paired comparisons resulted in differences across substrates that describe their unique water-retention properties.

The evaporation method allowed quantification of VWC at a higher soil tension than the frozen column method, and was therefore more accurate for quantifying $\theta_{r}$ and plant unavailable water for peat. However, for the low water potential substrates rockwool and foam, both methods were adequate. Similar information and statistical methods can be used with both methods; however, Altland et al. (2010) noted that the use of tensiometers requires a higher level of technical skill and has increased equipment cost compared with the frozen column substrate method (Table 2). We also noted greater variability in VWC data at low tensions with the tensiometer in rockwool and foam (Fig. 1). In addition to MRCs, the evaporation method has been used to describe hydraulic conductivity and substrate porosity (Fields et al., 2016, 2017; Naasz et al., 2005; Owen and Altland, 2008; Schindler, 1980; Schindler et al., 2016).

Method 3. Gravimetric whole-cell analysis. In small propagation cells, substrates held high VWC relative to VAC at container capacity using the gravimetric method, and there was a lower estimate in VWC and higher VAC in peat compared with the other two substrates (Table 3). Similar findings of high-water and low-air content in 2.2-cm-tall seedling plug cells were observed at container capacity in several peat:vermiculite ratios with different levels of compaction (Milks et al., 1989c). High moisture and low VAC of $<10 \%$ has been shown to have greater severity in root rot of toyon compared with VAC of $10 \%$ to $20 \%$ (Filmer et al., 1986).
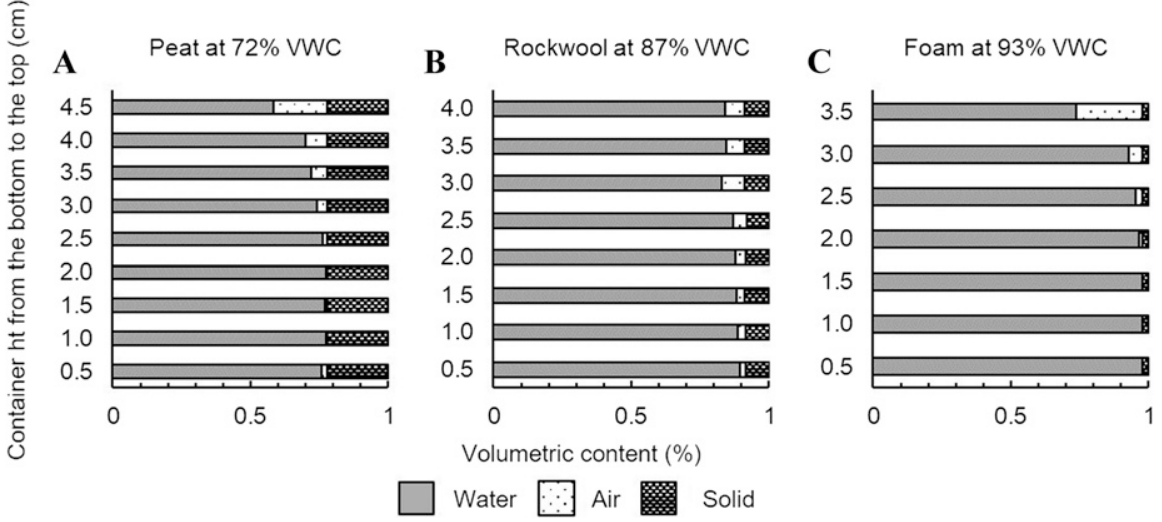

Fig. 3. Spatial quantification for (A) peat, (B), rockwool, and $(\mathbf{C})$ foam using computed tomography for volumetric water and air content at container capacity. Volumetric solid content was measured gravimetrically and used as a constant. Horizontal bars represent least squares means from $n=3$ replicates per substrate. X-axis is the total percent volumetric content. Y-axis is the container depth from the bottom to top $(\mathrm{cm})$.

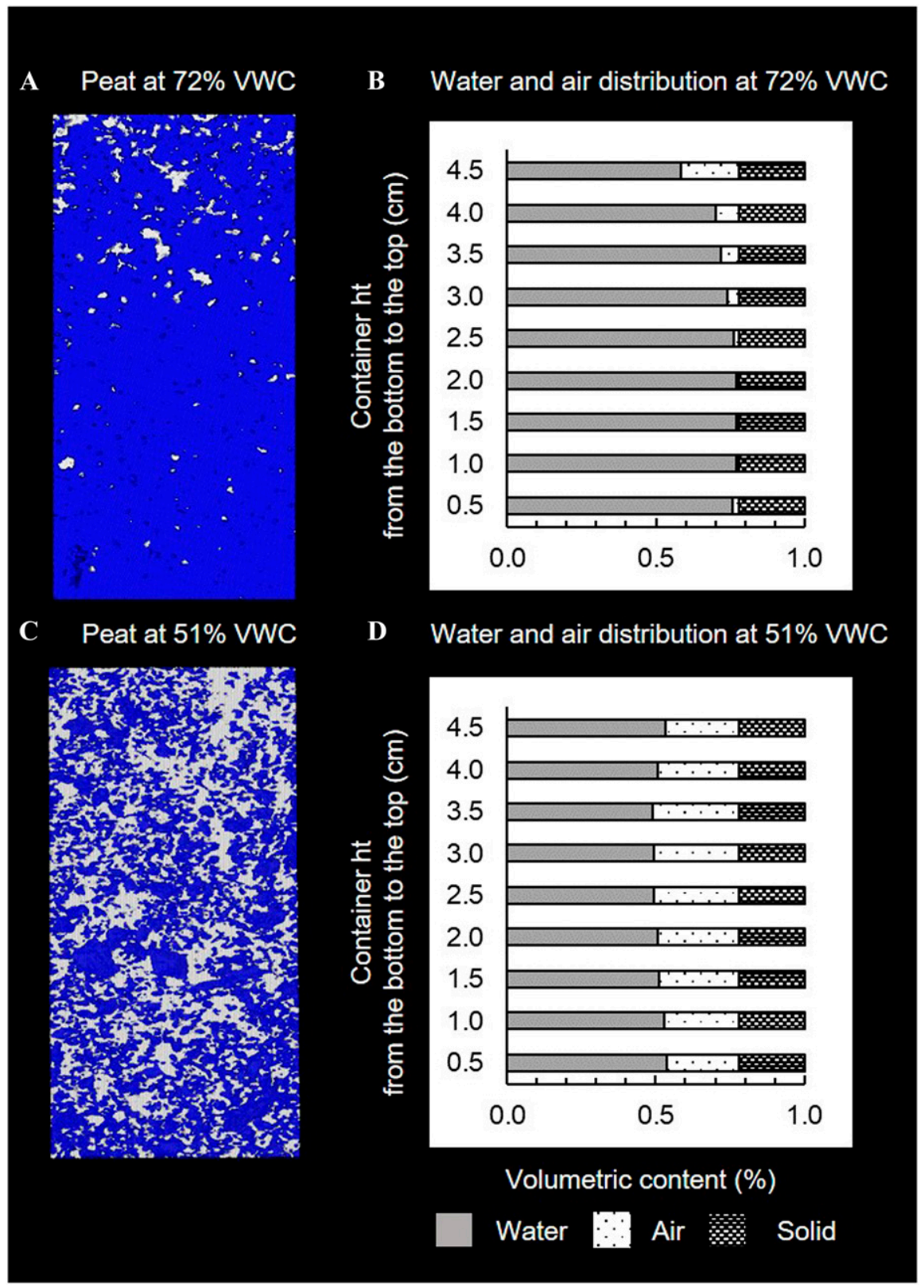

Fig. 4. CT images of peat and spatial quantification from container capacity $(\mathbf{A}, \mathbf{B})$ and as substrate dried to $51 \%$ VWC $(\mathbf{C}, \mathbf{D})$. Spatial quantification represents the least squares means of $n=3$ replicates per moisture level. 
Increasing container height results in increased air porosity, as gravity increases drainage in a given substrate, thus providing greater gradient of water throughout the vertical column. For example, foam at container capacity had a VAC of $30 \%$ in $15-\mathrm{cm}$-tall containers, but this deof VSC by $7 \%$ and underestimate of total porosity in small propagation cells for peat. It is likely that these discrepancies were due to compaction. Slowly increasing the height of water during subirrigation of peat in a basin and allowing at least two saturation/drainage cycles would improve water uptake because pockets of air exist in peat strands (Naasz et al., 2008). Gravimetric whole-cell analysis describes physical properties in small propagation cells, but does not represent the vertical cell (Table 2).

Method 4. X-ray tomography (CT) wholecell analysis. Quantification of VWC and VAC by gravimetric vs. CT scanning methods differed for peat but not for the other two substrates (Table 3). In our analysis, the solid content (and therefore total porosity) for the CT scans was based on the gravimetric analysis and was therefore not independent between methods. However, the division between VWC and VAC within total porosity was estimated by analysis of the CT digital image. Representative images of a tomography slice for each substrate is shown in Fig. 2. The peat image shows small air-filled pores more evenly distributed through the column compared with rockwool or foam. The rockwool shows an air-filled vertical line that arises from a planting slit designed during manufacturing to allow the cutting to be inserted. The large air-filled pore at the top right of the rockwool image shows that even though this is a manufactured substrate, there can be some variability in wettability and pore size. The foam image shows most of the airfilled pores occurring in the top of the cell. creased to $2 \% \mathrm{VAC}$ in 2.2 -cm-tall plug cells (Milks et al., 1989c). There was an overestimate distribution of water and air content within a

Spatial quantification of the propagation cells by $0.5-\mathrm{cm}$ sections found that air-filled pores were located mainly toward the top of the cell but were absent toward the bottom, and that water filled most pore spaces in all substrates (Fig. 3). In rockwool, air was mostly present in the vertical planting slit, which is part of the design of this propagation substrate to allow insertion of the plant cutting (Fig. 3B). The scan resolution was $59 \mu \mathrm{m}$, which means that VACs smaller than this resolution might exist, but were not quantified using this method and this may explain the lower estimate for VAC by CT for peat [internal pore size $\approx 15 \mu \mathrm{m}$ from Carey et al. (2007)] compared with the gravimetric method. A previous study by Fonteno (1989) described the spatial distribution of water and air in a tall container $(16.9 \mathrm{~cm})$ with volume of $3.9 \mathrm{~L}$. The spatial profile ranged from 1 to $16.9 \mathrm{~cm}$ in height by applying increasing tensions from $3.8,10,20,40,50,75,100$, 200 , and $300 \mathrm{~cm}$. The tall container had $58 \%$ VWC and 28\% VAC (Fonteno, 1989). In contrast, small cells $(55 \mathrm{~mL}$ and $4.5 \mathrm{~cm}$ height) in this study had $77 \%$ VWC and $1 \%$ VAC relative to the bottom $(1 \mathrm{~cm})$ of the container. This comparison further emphasizes the importance of quantifying the spatial distribution of water and air for a specific substrate and container size combination.

The CT image in Fig. 4 for peat at container capacity $(72 \%$ VWC) provides a visual representation that high moisture level is likely to block the movement of air, whereas allowing the substrate to dry to $51 \%$ VWC would increase the continuity of air-filled pores for gas exchange and oxygen supply to roots. This has implications for irrigation management, because providing wet-dry cycles would increase VAC to $>20 \%$ throughout the cell profile in peat (Fig. 4 and Table 4), which is in the range of air content that would not be limiting for root growth (DeBoodt and Verdonck, 1972; Gislerød, 1982; Handreck and Black, 2002).

Table 4. Cell spatial quantification by computed tomography (CT) for volumetric water content (VWC) or volumetric air content (VAC) in peat at container capacity $(72 \% \mathrm{VWC})$ and when substrate dried to medium moisture (51\% VWC), represented visually in Fig. 4. VWC or VAC by depth represents the least-square means of $\mathrm{n}=3$ replicates per moisture level and letters after VWC and VAC represent mean separation using Tukey's honestly significant difference at $\alpha=0.05$. Volumetric solid content was estimated at $22 \%$.

\begin{tabular}{lccc}
\hline Moisture level & Depth $(\mathrm{cm})$ & VWC, $\%$ & VAC, \% \\
\hline Container capacity & 0.5 & $58 \mathrm{c}$ & $20 \mathrm{~b}$ \\
& 1 & $70 \mathrm{~b}$ & $8 \mathrm{c}$ \\
1.5 & $72 \mathrm{ab}$ & $6 \mathrm{~cd}$ \\
2 & $74 \mathrm{ab}$ & $4 \mathrm{~cd}$ \\
& 2.5 & $76 \mathrm{ab}$ & $2 \mathrm{~cd}$ \\
3 & $77 \mathrm{a}$ & $1 \mathrm{~d}$ \\
Medium & $77 \mathrm{a}$ & $1 \mathrm{~d}$ \\
& 3.5 & $77 \mathrm{a}$ & $1 \mathrm{~d}$ \\
& 4 & $76 \mathrm{ab}$ & $2 \mathrm{~cd}$ \\
& 5.5 & $53 \mathrm{~cd}$ & $25 \mathrm{ab}$ \\
& 1 & $51 \mathrm{~d}$ & $27 \mathrm{a}$ \\
& 1.5 & $59 \mathrm{~d}$ & $29 \mathrm{a}$ \\
& 2 & $49 \mathrm{~d}$ & $28 \mathrm{a}$ \\
& 3.5 & $51 \mathrm{~d}$ & $29 \mathrm{a}$ \\
& 3.5 & $51 \mathrm{~d}$ & $27 \mathrm{a}$ \\
& $53 \mathrm{~d}$ & $27 \mathrm{a}$ \\
& 5.5 & $54 \mathrm{~cd}$ & $25 \mathrm{ab}$ \\
& & $24 \mathrm{ab}$ \\
\hline
\end{tabular}

Gravimetric whole-cell analysis was used to describe static substrate properties, and using the gravimetric estimate of VSC greatly simplified quantitative analysis by CT. Tracy et al. (2015a, 2015b) segmented all three components (solid, water, and air) in sandy and clay loam soils; however, with a substrate that absorbs water into internal pores, which is typical of propagation substrates, it becomes very difficult to segment the solid/water matrix. Gravimetric wholecell analysis was simple and quick in contrast to $\mathrm{CT}$, which requires specialized equipment and image segmentation software that is costly, complicated, and time-consuming (Table 2). Estimated time from start to finish for CT quantitative analysis of one sample was 1.5 to $3.0 \mathrm{~h}$, not considering protocol development and software competence. The CT analysis allowed for spatial stratification and visualization of complex water and air relations within substrates. Both gravimetric and CT methods provide static characteristics, but by analyzing substrates at different moisture levels, such as shown in Fig. 4, these methods can be combined with evaporation data to generate MRCs (Daly et al., 2015).

\section{Conclusion}

Water and air relations of three propagation substrates were quantified by evaporation or frozen column methods. MRCs described low water potential in rockwool and foam compared with peat. There was also more consistency in MRC between the two methods for rockwool and foam compared with peat. Gravimetric and CT methods resulted in similar estimates of volumetric water and air content at container capacity in rockwool and foam, but VWC estimates differed in peat between methods. In propagation cells, all substrates held high water content, and most pores were filled with water at container capacity, meaning that waterlogging would be possible with all substrates under poor control of mist irrigation. Peat had an even distribution of water as it dried from container capacity to $51 \%$ VWC. It would be useful to quantify water distribution in the three substrates under a range in moisture conditions. Peat had higher water-buffering capacity than rockwool or foam, which on the one hand would aid in cutting hydration because the substrate would dry slowly, but also increases the risk of over watering. Irrigation strategy based on substrate water potential is necessary to ensure adequate balance of water and air appropriate to the production phase.

\section{Literature Cited}

Altland, J.E., J.S. Owen, Jr., and W.C. Fonteno 2010. Developing moisture characteristic curves, and their descriptive functions at low tensions for soilless substrates. J. Amer. Soc. Hort. Sci. 35:563-567.

Argo, W.R., J.A. Biernbaum, and W.C. Fonteno. 1996. Root medium carbon dioxide and oxygen partial pressure for container-grown Chrysanthemum. HortScience 32:385-388. 
Bilderback, T.E. and M.R. Lorscheider. 1995. Physical properties of double-processed pine bark: Effects on rooting. Acta Hort. 401: 77-83.

Bilderback, T.E., S.L. Warren, J.S. Owen, Jr., and J.P. Albano. 2005. Healthy substrates need physicals too! HortTechnology 15:747-751.

Carey, S.K., W.L. Quinton, and N.T. Goeller. 2007. Field and laboratory estimates of pore size properties and hydraulic characteristics for subarctic organic soils. Hydrol. Processes 21(429): 2560-2571.

Caron, J. and V.K.N. Nkongolo. 1999. Aeration in growing media: Recent developments. Acta Hort. 481:545-551.

Chérif, M., Y. Tirilly, and R.R. Belanger. 1997. Effect of oxygen concentration on plant growth, lipidperoxidation, and receptivity of tomato roots to Pythium under hydroponic conditions. Eur. J. Plant Pathol. 103:255-264.

Daly, K.R., S.J. Mooney, M.J. Bennett, N.M.J. Crout, T. Roose, and S.R. Tracy. 2015. Assessing the influence of the rhizosphere on soil hydraulic properties using X-ray computed tomography and numerical modelling. J. Expt. Bot. 66:2305-2314.

Dane, J.H. and J.W. Hopmans. 2002. Pressure plate extractor, p. 688-690. In: J.H. Dane and E.C. Topp (eds.). Methods of soil analysis, part 4, physical methods. SSSA Book Ser. 5. SSSA, Madison, WI.

da Silva, F.F., R. Wallach, and Y. Chen. 1993. Hydraulic properties of sphagnum peat moss and tuff (scoria) and their potential effects on water availability. Plant Soil 154:119-126.

da Silva, F.F., R. Wallach, and Y. Chen. 1995. Hydraulic properties of rockwool slabs used as substrates in horticulture. Acta Hort. 401: 71-75.

DeBoodt, M. and O. Verdonck. 1972. Physical properties of peat and peat-moulds improved by perlite and foam-plastics in relation to ornamental plant-growth. Acta Hort. 18:9-27.

Fields, J.S., J.S. Owen, Jr., L. Zhang, and W.C. Fonteno. 2016. Use of the evaporative method for determination of soilless substrate moisture characteristic curves. Scientia Hort. 211:102-109.

Fields, F.S., J.S. Owen, Jr., and H.L. Scoggins. 2017. The influence of substrate hydraulic conductivity on plant water status of an ornamental container crop grown in suboptimal substrate water potentials. HortScience 52:1419-1428.

Filmer, C.L.R., J.D. MacDonald, J.L. Paul, and A.T. Leiser. 1986. Influence of air-filled porosity of container media on Phytophthora root rot of toyon. HortScience 21:1010-1011.

Fonteno, W.C. 1989. An approach to modeling air and water status of horticultural substrates. Acta Hort. 238:67-74.

Fonteno, W.C. 1993. Problems \& considerations in determining physical properties of horticultural substrates. Acta Hort. 342:197-204.
Fonteno, W.C. and P.V. Nelson. 1990. Physical properties of and plant responses to rockwoolamended media. J. Amer. Soc. Hort. Sci. 115:375-381.

Gislerød, H.R. 1982. Physical conditions of propagation media and their influence on the rooting of cuttings. Plant Soil 69:445-456.

Gislerød, H.R. 1983. Physical conditions of propagation media and their influence on the rooting of cuttings. Plant Soil 75:1-14.

Handreck, K. and N. Black. 2002. Growing media for ornamental plants and turf, 3rd ed. University of South Wales Press, Sydney, NSW, Australia.

Healy, W. 2008. How wet is wet? Watering terminology. OFA Bulletin 907:16-18.

Heiskanen, J. 1995. Physical properties of twocomponent growth media based on Sphagnum peat and their implications for plant available water and aeration. Plant Soil 172:45-54.

Huang, J., P.R. Fisher, and W.R. Argo. 2012a Media quality control for young plant growers: Substrate particle size. Ohio Florists' Assoc. Bul. March/April, 932:1-12.

Huang, J., P.R. Fisher, and W.R. Argo. 2012b Quality control in growing media: Porosity for plug and liner mixes. Ohio Florists' Assoc. Bul. November/December, 934:2-7.

Huang, J. and P.R. Fisher. 2014. Quality control procedures in container growing substrates for young plant production. Acta Hort. 1034:263-268.

Kiehl, P.A., J.H. Lieth, and D.W. Burger. 1992. Growth response of chrysanthemum to various container medium moisture tension levels. J. Amer. Soc. Hort. Sci. 117:224-229.

Leakey, R.R.B. 2004. Physiology of vegetative reproduction, p. 1655-1668. In: J. Burley, J. Evans, and J.A. Youngquist (eds.). Encyclopedia of forest sciences. Academic Press, London, UK.

Loach, K. 1988. Characterisation of optimal environments for rooting leafy cuttings. Acta Hort. 226:403-412.

Milks, R.R., W.C. Fonteno, and R.A. Larson 1989a. Hydrology of horticultural substrates: I. Mathematical models for moisture characteristics of horticultural container media. J. Amer. Soc. Hort. Sci. 114:48-52.

Milks, R.R., W.C. Fonteno, and R.A. Larson. 1989b. Hydrology of horticultural substrates: II. Predicting physical properties of media in containers. J. Amer. Soc. Hort. Sci. 114:53-56.

Milks, R.R., W.C. Fonteno, and R.A. Larson. 1989c. Hydrology of horticultural substrates: III. Predicting air and water content of limited volume plug cells. J. Amer. Soc. Hort. Sci. 114:57-60.

Naasz, R., J.-C. Michel, and S. Charpentier. 2005. Measuring hysteretic hydraulic properties of peat and pine bark using a transient method. Soil Sci. Soc. Amer. J. 69:13-22.
Naasz, R., J.-C. Michel, and S. Charpentier. 2008. Water repellency of organic growing media related to hysteretic water retention properties. Eur. J. Soil Sci. 59:156-165.

Nimmo, J.R. 2004. Porosity and pore size distribution, p. 295-303. In: D. Hillel (ed.). Encyclopedia of soils in the environment, vol. 3. Elsevier, London, UK.

Owen, J.S., Jr. and J.E. Altland. 2008. Container height and douglas fir bark texture affect substrate physical properties. HortScience 43:505508.

Puustjarvi, V. and R.A. Robertson. 1975. Physical and chemical properties, p. 23-28. In: D.W. Robinson and J.G.D. Lamb (eds.). Peat in horticulture. Academic Press, New York, NY.

Reisch, K.W. 1967. Rooting media. Proc. Intl. Plant Prop. Soc. 117:356-361.

Rivière, L.-M. and J. Caron. 2001. Research on substrates: State of the art and need for the coming 10 years. Acta Hort. 548:29-41 (ISHS, Proc. Int. Symp. On Growing Media \& Hydroponics).

Santos, K.M., P.R. Fisher, T. Yeager, E.H. Simonne, H.S. Carter, and W.R. Argo. 2011. Timing of macronutrient supply during cutting propagation of Petunia. HortScience 43:475480.

Schindler, U. 1980: Ein Schnellverfahren zur Messung der Wasserleitfähigkeit im teilgesättigten Boden an Stechzylinderproben. Archiv für Acker- und Pflanzenbau und Bodenkunde 24(1):1-7.

Schindler, U., L. Müller, and F. Eulenstein. 2016. Measurement and evaluation of the hydraulic properties of horticultural substrates. Arch. Agron. Soil Sci. 62:806-818.

Tracy, S.R., C.R. Black, J.A. Roberts, and S.J. Mooney. 2013. Exploring the interacting effect of soil texture and bulk density on root system development in tomato (Solanum lycopersicum L.). Environ. Expt. Bot. 91:38-47.

Tracy, S.R., C.R. Black, J.A. Roberts, I.C. Dodd, and S.J. Mooney. 2015a. Using x-ray computed tomography to explore the role of abscisic acid in moderating the impact of soil compaction on root system architecture. Environ. Expt. Bot. 110:11-18.

Tracy, S.R., K.R. Daly, C.J. Sturrock, N.M.J. Crout, S.J. Mooney, and T. Roose. 2015b. Three-dimensional quantification of soil hydraulic properties using $\mathrm{x}$-ray computed tomography and image-based modeling. Water Resour. Res. 51:1006-1022.

van Genuchten, M.Th. 1980. A closed-form equation for predicting the hydraulic conductivity of unsaturated soils. Soil Sci. Soc. Amer. J. 44: 892-898.

Wallach, R. 2008. Physical characteristics of soilless media, p. 41-108. In: M. Raviv and J.H. Lieth (eds.). Soilless culture: Theory and practice. Elsevier, Burlington, MA 